University of Nebraska - Lincoln

DigitalCommons@University of Nebraska - Lincoln

USDA Wildlife Services - Staff Publications

U.S. Department of Agriculture: Animal and Plant Health Inspection Service

February 2005

\title{
Efficacy of an animal-activated frightening device on urban elk and mule deer
}

Kurt C. VerCauteren

USDA-APHIS-Wildlife Services, kurt.c.vercauteren@usda.gov

John A. Shivik

Michael J. Lavelle

USDA/APHIS/WS National Wildlife Research Center, michael.j.lavelle@aphis.usda.gov

Follow this and additional works at: https://digitalcommons.unl.edu/icwdm_usdanwrc

Part of the Environmental Sciences Commons

VerCauteren, Kurt C.; Shivik, John A.; and Lavelle, Michael J., "Efficacy of an animal-activated frightening device on urban elk and mule deer" (2005). USDA Wildlife Services - Staff Publications. 518.

https://digitalcommons.unl.edu/icwdm_usdanwrc/518

This Article is brought to you for free and open access by the U.S. Department of Agriculture: Animal and Plant Health Inspection Service at DigitalCommons@University of Nebraska - Lincoln. It has been accepted for inclusion in USDA Wildlife Services - Staff Publications by an authorized administrator of DigitalCommons@University of Nebraska - Lincoln. 


\section{Efficacy of an animal-activated frightening device on urban elk and mule deer}

\section{Kurt C. VerCauteren, John A. Shivik, and Michael J. Lavelle}

Abstract Cervids readily adapt to suitable human-altered landscapes and can cause several types of damage, including economic loss associated with landscape and agricultural plantings, human health and safety concerns, and adverse impacts on natural habitats. The need for effective, practical, and nonlethal tools to manage damage caused by elk (Cervus elaphus), mule deer (Odocoileus hemionus), and white-tailed deer (Odocoileus virginianus) has been heightened by the growing prevalence of locally overabundant populations and public demand for nonlethal wildlife management methods. Various frightening devices are available commercially, but most have not been subjectively evaluated. We used consumption measurements to evaluate the efficacy of a specific motion-activated light- and sound-emitting frightening device for urban mule deer and elk. The devices proved ineffective; deer and elk ignored them. As the demand for frightening devices to reduce deer and elk damage increases, it is important that research be conducted to evaluate the efficacy of new devices so that users know what level of efficacy to expect.

Key words Cervus elaphus, Critter Gitter ${ }^{\mathrm{T} M}$, elk, frightening device, mule deer, Odocoileus hemionus, wildlife damage management

The need for site- and time-specific methods of deterring elk (Cervus elaphus) and deer (Odocoileus spp.) damage in both urban and rural environments continues to intensify. In urban areas elk and deer often habituate to humans and consume abundant and high-quality foods such as vegetable gardens, ornamental plants, and fertilized lawns (Swihart et al. 1995, Conover 1997a, Kie and Czech 2000). These food resources and absence of predators (including hunters) allow elk and deer to thrive in these areas. In rural regions the majority of cervid diets may consist of agricultural crops (Austin and Urness 1993, Austin et al. 1998, Wisdom and Cook 2000). Most agricultural producers reported crop damage from elk and deer and claim these animals caused more damage than other wildlife species (Conover and Decker 1991, Conover 1994, Wywialowski 1994). Conover (1997b) conservatively estimated annual agriculture damage from deer at $\$ 100$ million (U.S.). Elk and mule deer (O. hemionus) were a major tourist attraction in Estes Park, Colorado, USA, but also caused damage to gardens, ornamentals, agricultural crops, and golf courses (Singer et al. 2002). Elk also are involved in about 1 vehicle collision per day during the breeding season (R. Spowart, Colorado Division of Wildlife, personal communication).

Successful damage-reduction strategies should be easy to implement prior to and while damage is

Address for Kurt C. VerCauteren and Michael J. Lavelle: United States Department of Agriculture, Animal and Plant Health Inspection Service, Wildlife Services, National Wildlife Research Center, 4101 LaPorte Avenue, Fort Collins, CO 80521-2154, USA; email for VerCauteren: kurt.c.vercauteren@aphis.usda.gov. Address for John A. Shivik: United States Department of Agriculture, Animal and Plant Health Inspection Service, Wildlife Services, National Wildlife Research Center, Room 163 B. N. R. Building, Utah State University, Logan, UT 84322-5230, USA. 
occurring and should be part of an overall integrated cervid-management program. Several types of fences effectively reduce or prevent cervid damage (Craven and Hygnstrom 1994, DeCalesta and Witmer 1994, Lavelle to VerCauteren et al. unpublished data) but may not be cost-effective relative to the value of the resource being protected, even if pro-rated over the life of the fence (Lavelle to VerCauteren et al.unpublished data). Cervid populations can be managed effectively through hunting (VerCauteren and Hygnstrom 1998, Woolf and Roseberry 1998, Brown et al. 2000, VerCauteren and Hygnstrom 2002), though it may not be safe, practical, or socially acceptable in urban and suburban settings.

Most research evaluating frightening devices for cervids has focused on white-tailed deer (O. virginianus) (Belant et al. 1996, Belant et al. 1998, Beringer et al. 2003); little has been published regarding the efficacy of frightening devices for elk and mule deer (Krausman et al. 1996). Cervids typically habituate quickly to "frightening" sounds, sights, or smells (Bomford and O'Brien 1990, Koehler et al. 1990, Gilsdorf et al. 2003). Shell crackers, gunfire, propane cannons, scarecrows, and similar frightening devices generally are ineffective, even for short time periods (Koehler et al. 1990, Belant et al. 1996, Gilsdorf et al. 2004a). Conversely, Beringer et al. (2003) evaluated a motion-activated frightening device with acoustic and visual stimuli that repelled white-tailed deer from soybean plots for 6 weeks, though efficacy decreased late in the study. Two other motion-activated frightening devices proved ineffective for white-tailed deer (Belant et al. 1998, Gilsdorf et al. 2004b).

Damage by cervids and other wildlife on suburban landscapes has spawned an interest in developing products designed to repel animals. Our goal was to evaluate one of these products, a motionactivated electronic frightening device, on mule deer and elk.

\section{Methods}

We evaluated a frightening device marketed to homeowners to protect gardens or landscaping. The Critter Gitter ${ }^{\mathrm{TM}}$ (Amtek, San Diego, Calif.) was a compact, battery-operated device activated when passive-infrared sensors detected movement and body heat within a $90^{\circ}$ arc of the device and out to a maximum of $50 \mathrm{~m}$ (manufacturer statement). The device activated for $5 \mathrm{sec}$ each time the sensor

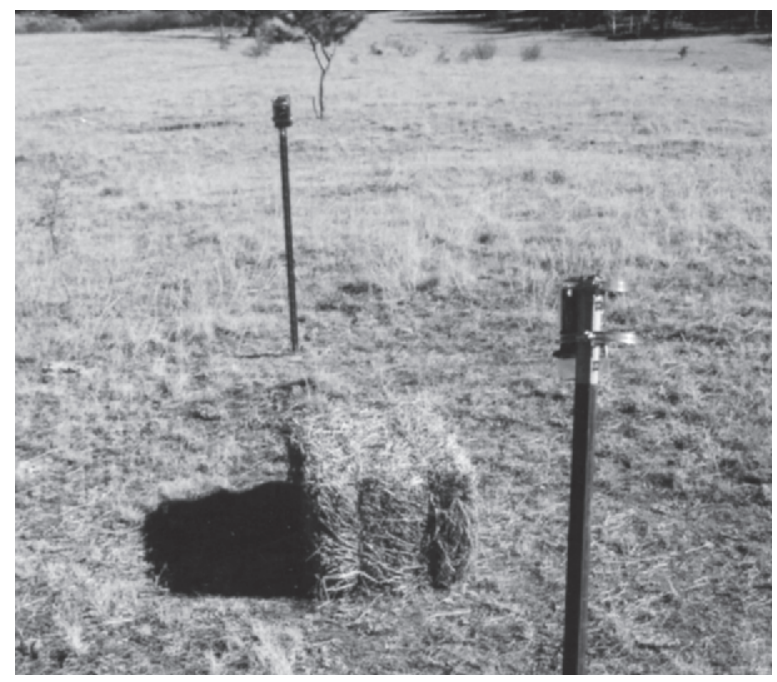

Figure 1. A protected test bale of alfalfa placed within sensory range of 2 Critter Gitters ${ }^{\text {TM }}$, Estes Park, Colorado, USA, 2001.

detected movement. The alarm approached 120 decibels in volume (manufacturer statement) and consisted of a repeated series of low- to highpitched beeps that varied in pattern each time the device was activated. A pair of red, light-emitting diodes designed to simulate predator eyes (manufacturer statement) flashed on the front of the device while the alarm sounded.

We conducted the study on 5 independent sites (>300 $\mathrm{m}$ apart, not visible from each other) in pastures on a private ranch abutting residential areas of the city of Estes Park, Colorado, USA. We selected sites based on similar vegetation, topography, and proximity to timber. Each site contained 2 bales of alfalfa situated $60 \mathrm{~m}$ apart. We randomly applied 1 of 2 treatments ( 1 or 2 devices) to 1 bale and no treatment to the other. On sites 1 and 2, a single device was centered on the top of the bale with its motion sensor and speaker directed upward. On sites 3-5, we used 2 devices mounted $1 \mathrm{~m}$ high on metal T-posts, $2 \mathrm{~m}$ from each end of the bale with sensory fields centered on the bale (Figure 1). Devices triggered only when animals were $\leq 2 \mathrm{~m}$ from the bale.

On 10 check days (every 2-3 days), we visually inspected the bales and recorded whether hay consumption had occurred since the previous check day. We estimated hay consumption (percentage of bale consumed to the nearest 5\%) based on on-site visual comparisons of the test bale to an undamaged bale. We then calculated the amount of consumption $(\mathrm{kg})$ by multiplying the percentage miss- 


\section{Wildife Society Bulletin 2005, 33(4):1282-1287}

ing by an average bale weight of $29.3 \mathrm{~kg}$. We practiced estimating missing percentages of bales prior to the study and our estimates were consistent within and among observers. On each check day, we tested devices to ensure consistent and comparable performance. At the conclusion of the study, we used a decibel meter (Impulse Precision Soundlevel Meter T1200, Bruel and Kjaer, Naerum, Denmark) to determine whether the device's alarm output was similar to what the manufacturer reported.

To document reactions of animals to the devices, throughout the study we monitored protected and unprotected bales on 2 randomly selected sites with motion-activated video systems (Trailmaster ${ }^{\circledR}$ TM 700v, Goodson \& Associates, Inc., Lenexa, Kans.). The video systems consisted of passiveinfrared sensors that operated video cameras (Sony Handycam $^{\circledR}$, Sony Corporation, Tokyo, Japan) and red-filtered lights that illuminated when systems were activated during darkness. Once activated, the systems would record as long as the animal remained active within a $12-\mathrm{m}$ sensory zone.

We evaluated a research hypothesis that Critter Gitters would reduce hay consumption by testing a null hypothesis that consumption would not differ among treatment levels ( 0,1 , and 2 devices/bale). We modeled hay consumption as a function of site, treatment, day, and all interactions (PROC MIXED, SAS Institute, Inc. 2003). We accounted for repeated measures on experimental units (bales) by modeling correlation among measurement occasions (days) using a generalized auto regressive structure to account for unequal measurement intervals (spatial power law, Littell et al. 1996).

\section{Results}

We recorded data from the 5 sites on 10 check days. On the first 2 and last check days at Site 1, and the last 2 check days at Site 2, the devices were not functioning properly, so data from these days were not included in the analyses. We conducted 15 inspections on protected and unprotected bales with 1 Critter Gitter and 30 inspections on those with 2 Critter Gitters. On sites with 1 Critter Gitter, we documented consumption on protected bales on 5 of 15 inspections (33\%) and consumption of unprotected bales on 8 of 15 (53\%) inspections. On sites with 2 Critter Gitters, we found equal damage frequency on protected and unprotected bales, with consumption occurring on 13 of 30 (43\%)

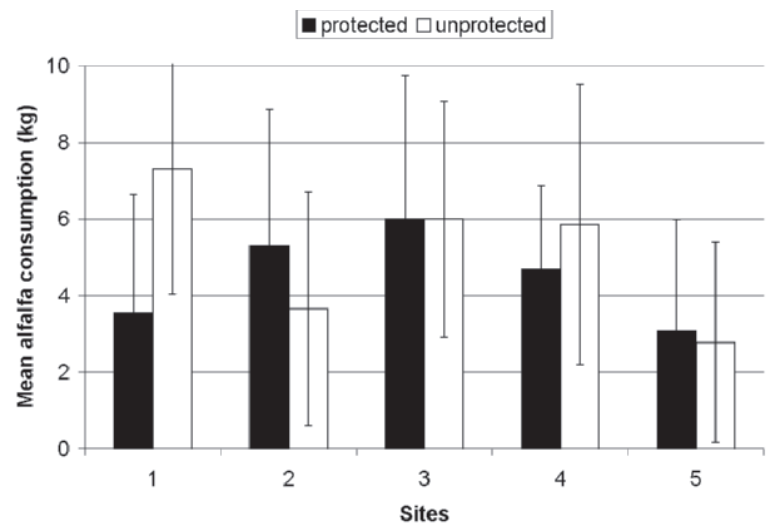

Figure 2. Mean consumption (SE) by elk and mule deer on 5 protected and 5 unprotected bales of alfalfa, Estes Park, Colorado, USA, 2001.

inspections. We found no differences in estimated consumption of bales $\left(F_{2,51.8}=0.37, P=0.691\right.$; Table 1 , Figure 2$)$ protected with 1 device $(\bar{x}=4.48 \mathrm{~kg}, \mathrm{SE}$ $=2.31, n=15), 2$ devices $(\bar{x}=4.58 \mathrm{~kg}, \mathrm{SE}=1.70, n=$ $30)$, or 0 devices ( $\bar{x}=5.04 \mathrm{~kg}, \mathrm{SE}=1.42, n=45)$.

Video data from protected bales showed mule deer to be momentarily startled by the device on 6 of 29 (21\%) recorded events, but they were never deterred from feeding. Elk were never observed to be startled in 15 recorded events. Elk or mule deer fed on bales while the device was activated during all 44 recorded events (Figure 3).

\section{Discussion}

We found Critter Gitters to be ineffective for deterring elk and mule deer from feeding. Variability in consumption amounts, though not significant, likely was due to the itinerant feeding habits of elk rather than effects of the device. We are confident that our visual estimates of consump-

Table 1. Repeated-measures analyses of hay consumption at bales protected by 1, 2, or 0 Critter Gitters ${ }^{\mathrm{T}}$, Estes Park, Colorado, USA, 2001.

\begin{tabular}{lcccc}
\hline & \multicolumn{4}{c}{$\mathrm{df}$} \\
\cline { 3 - 5 } Effects & $F$ & Numerator & Denominator & $P$ \\
\hline Day & 5.22 & 1 & 51.1 & 0.027 \\
Site & 0.16 & 4 & 52.9 & 0.960 \\
Treatment & 0.37 & 2 & 51.8 & 0.691 \\
Day $\times$ Site & 0.14 & 4 & 49.7 & 0.966 \\
Day $\times$ Treatment & 0.56 & 2 & 49.8 & 0.572 \\
Treatment $\times$ Site & 0.06 & 3 & 52.8 & 0.979 \\
Day $\times$ Treatment $\times$ Site & 0.35 & 3 & 48.7 & 0.789 \\
\hline
\end{tabular}




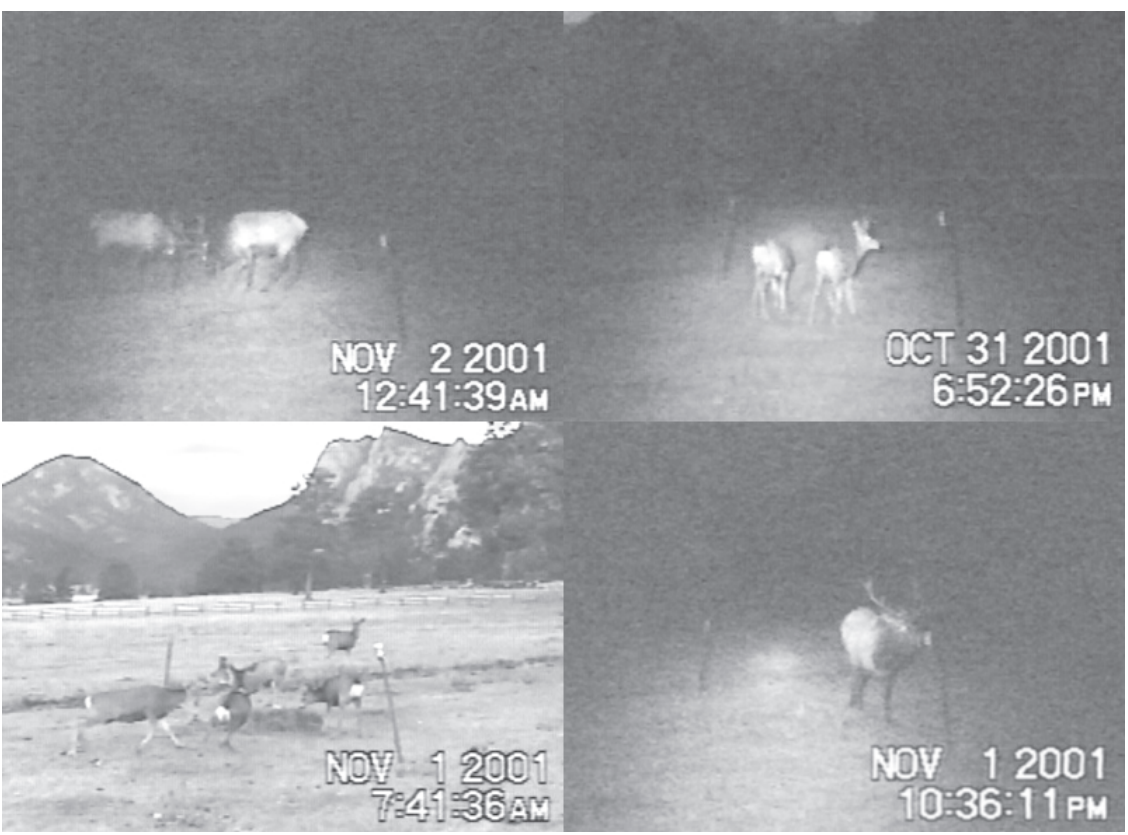

Figure 3. Elk and mule deer visiting sites protected by Critter Gitters ${ }^{\mathrm{TM}}$, Estes Park, Colorado, USA, 2001

tion adequately reflected actual consumption. We may have amassed more accurate consumption data had we determined the weight and moisture content of bales at the beginning and end of each check period, correcting for moisture content at the end of a check period, and subtracting this value from the beginning weight to determine amount consumed. As correcting for moisture level changes in bales would have been problematic and labor-intensive, for the scope of this study we opted to visually estimate consumption.

We recorded 44 events on video of elk or mule deer feeding on protected bales while devices were activated and found no deterrence of consumption by the alarm and flashing red lights. White-tailed deer do not have the visual capability to see red light (VerCauteren and Pipas 2003), and VerCauteren et al. (2003) reported that white-tailed deer did not react to red laser light. Consequently, it was unlikely that elk or mule deer could see the red lights of Critter Gitters. The manufacturer stated that the output of the device approached 120 decibels. We found this to be true when the device was within $0.5 \mathrm{~m}$ of the decibel meter.

We observed elk and mule deer in our study to regularly be $<50 \mathrm{~m}$ from human dwellings, vehicles, and livestock. Others also have observed elk (Singer et al. 2002) and mule deer (Wolfe et al.
2004) in this area to commonly be close to dwellings. The comfort level of these cervids with the sights and sounds of human habitation may account for their lack of response. Critter Gitters may be more effective on elk and deer that are not habituated. One problem we encountered with the Critter Gitters was that they were occasionally triggered by non-animalrelated stimuli, possibly changes in ambient temperature or solar radiation. By activating when animals were not feeding on protected bales, nearby elk and deer may have habituated to the alarms more quickly than would have occurred if the devices activated only in their presence.

Other frightening devices reported to be ineffective include propane cannons (Koehler et al. 1990, Gilsdorf et al. 2004a), lights (Koehler et al. 1990), ultrasonic noise makers (Curtis et al. 1997, Belant et al. 1998), and some multi-stimuli devices (Roper and Hill 1985, Koehler et al. 1990, Belant et al. 1998). A common problem with many frightening devices is the short duration of efficacy due to rapid habituation by the target species (Gilsdorf et al. 2003). Others have recommended and documented several general methods for improving efficacy of frightening devices, including use of a variety of stimuli (Shivik and Martin 2000, Beringer et al. 2003), frequent movement of devices (Koehler et al. 1990), and that devices be animal-activated (Belant et al. 1996, 1998; Beringer et al. 2003). As Critter Gitters were animal-activated, they had potential to provide protection to alfalfa bales from elk and mule deer. However, because they failed to protect the hay, we speculate that they also would be ineffective in deterring elk or mule deer from feeding in gardens, golf courses, ornamental plantings, fertilized lawns, or other similar areas.

Acknowledgments. T. Linder, B. Schmit, D. Martin, and S. Breck helped with field work. G. Phillips and 
S. Werner provided statistical assistance. The reviews of D. Whittaker, J. L. Bowman, and 2 anonymous reviewers strengthened the manuscript. All procedures were approved by the United States Department of Agriculture-Animal and Plant Health Inspection Service-Wildlife Services-National Wildlife Research Center's (NWRC) Institutional Animal Care and Use Committee. Reference to trade names does not imply United States government endorsement of commercial products or exclusion of similar products with equal or better effectiveness.

\section{Literature cited}

Austin, D. D.,AND P. J. URNess. 1993. Evaluating production losses from mule deer depredation in alfalfa fields. Wildlife Society Bulletin 21:397-401.

Austin, D. D., P. J. Urness, AND D. DuersCh. 1998. Alfalfa hay crop loss due to mule deer depredation. Journal of Range Management 51:29-31.

Belant, J. L., T. W. SEAmans, AND C. P. Dwyer. 1996. Evaluation of propane exploders as white-tailed deer deterrents. Crop Protection 15:575-578.

Belant, J. L.,T.W. Seamans,and L.A.Tyson. 1998. Evaluation of electronic frightening devices as white-tailed deer deterrents. Proceedings of the Vertebrate Pest Conference 18: 107-110.

Beringer, J., K. C. VerCauteren, and J. J. Milspaugh. 2003. Evaluation of an animal-activated scarecrow and monofilament fence for reducing deer use of soybean fields. Wildlife Society Bulletin 31:492-498.

BOMFORD, M.,AND P. H. O'BRIEN. 1990. Sonic deterrents in animal damage control: a review of device tests and effectiveness. Wildlife Society Bulletin 18:411-422.

Brown, T. L., D. J. Decker, S. J. Riley, J. W. Enck, T. B. Lauber, P. D. Curtis, and G. F. Matfeld. 2000. The future of hunting as a mechanism to control white-tailed deer populations. Wildlife Society Bulletin 28: 797-807.

Conover, M. R. 1994. Perceptions of grass-roots leaders of the agricultural community about wildlife damage on their farms and ranches. Wildlife Society Bulletin 22:94-100.

Conover, M. R. 1997a. Wildlife management by metropolitan residents in the United States: practices, perceptions, costs, and values. Wildlife Society Bulletin 25:306-311.

CONOVER, M. R. 1997b. Monetary and intangible valuation of deer in the United States. Wildlife Society Bulletin 25: 298-305.

CONOVER, M. R.,AND D. J. DeCKer. 1991. Wildlife damage to crops: perceptions of agricultural and wildlife professionals in 1957 and 1987. Wildlife Society Bulletin 19:6-52.

Craven, S. R., and S. E. Hygnstrom. 1994. Deer. Pages D25-40 in S. E. Hygnstrom, R. M. Timm, and G. E. Larson, editors. Prevention and control of wildlife damage. University of Nebraska Cooperative Extension, Lincoln, USA.

CuRTis, P. D., C. FitZgerald, AND M. E. Richmond. 1997. Evaluation of the Yard Gard ultrasonic yard protector for repelling white-tailed deer. Proceedings of the Eastern Wildlife Damage Control Conference 7:172-176.

DeCalesta, D. S., and G.W.Witmer. 1994. Elk. Pages D41-D50 in S. E. Hygnstrom, R. M. Timm, and G. E. Larson, editors.
Prevention and control of wildlife damage. University of Nebraska Cooperative Extension, Lincoln, USA.

Gilsdorf, J. M., S. E. Hygnstrom, and K. C.VerCauteren. 2003. Use of frightening devices in wildlife damage management. Integrated Pest Management Reviews 7:29-45.

Gilsdorf, J. M., S. E. Hygnstrom, K. C.VerCauteren, E. E. Blankenship, and R. M. Engemann. 2004a. Propane exploders and electronic guards were ineffective at reducing deer damage in cornfields. Wildlife Society Bulletin 32:524-531.

Gilsdorf, J. M., S. E. Hygnstrom, K. C.VerCauteren, G. M. Clements, E. E. Blankenship, AND R. M. ENGEMANn. 2004b. Evaluation of a deer-activated bio-acoustic frightening device for reducing deer damage in cornfields. Wildlife Society Bulletin 32: 515-523.

KIE, J. G., AND B. CZeCH. 2000. Mule and black-tailed deer. Pages 629-657 in S. Demarais and P. R. Krausman, editors. Ecology and management of large mammals in North America. Prentice Hall, Upper Saddle River, New Jersey, USA.

Koehler, A. E., R. E. Marsh, and T. P. Salmon. 1990. Frightening methods and devices/stimuli to prevent mammal damage - a review. Proceedings of the Vertebrate Pest Conference 14: 168-173.

Krausman, P. R., M. E. Weisenberger, M. C. Wallace, B. Czech, D. W. DeYoung,and O. E. Maughan. 1996. Behavioral responses of mule deer and mountain sheep to simulated aircraft noise. Desert Bighorn Council Transactions 40:1-7.

Littell, R. C., G. A. Milliken, W. W. Stroup, AND R. D. Wolfinger. 1996. SAS System for mixed models. SAS Institute, Inc., Cary, North Carolina, USA.

ROPER, R. B.,AND E. P. HILL. 1985. An evaluation of visual and auditory electronic devices to repel deer. Proceedings of the Eastern Wildlife Damage Control Conference 2:186-191.

SAS InStitute, Inc. 2003. SAS System for Windows. Release 9.1. SAS Institute, Cary, North Carolina, USA.

SHIVIK, J.A., AND D. J. MarTin. 2000. Aversive and disruptive stimulus applications for managing predation. Proceedings of the Wildlife Damage Management Conference 9:111-119.

Singer, F. J., L. C. Zeigenfuss, B. Lubow, ANd M. J. Rock. 2002. Ecological evaluation of potential overabundance of ungulates in U.S. National Parks: a case study. Pages 205-248 in F. J. Singer and L. C. Zeigenfuss, compilers. Ecological evaluation of the abundance and effects of elk herbivory in Rocky Mountain National Park, Colorado, 1994-1999. United States Geological Survey and Natural Resources Ecology Laboratory, Colorado State University, Fort Collins, USA.

Swithat, R. K., P. M. Picone, A. J. DeNicola, and L. Cornicelli. 1995. Ecology of urban and suburban white-tailed deer. Pages 35-44 in J. B. McAninch, editor. Urban deer: a manageable resource? Proceedings of the 1993 Symposium of the North Central Section, The Wildlife Society. Saint Louis, Missouri, USA

VerCauteren, K. C., and S. E. Hygnstrom. 1998. Effects of agricultural activities and hunting on home ranges of female white-tailed deer. Journal of Wildlife Management 62: 280-285.

VerCauteren, K. C., and S. E. Hygnstrom. 2002. Efficacy of hunting for managing a suburban deer population in eastern Nebraska. Proceedings of the National Bowhunting Conference 1:51-58

VerCauteren, K. C., S. E. Hygnstrom, M. J. Pifas, P. B. Fioranelu, S. J. WERNER, AND B. F. BLACKWELL. 2003. Red lasers are ineffective for dispersing deer at night. Wildlife Society Bulletin 31: 247-252. 
VerCauteren, K. C., and M. J. Pipas. 2003. A review of color vision in white-tailed deer. Wildlife Society Bulletin 31:684-691.

WisDOM, M. J., AND J. G. COOK. 2000. North American Elk. Pages 694-735 in S. Demarais and P. R. Krausman, editors. Ecology and management of large mammals in North America. Prentice Hall, Upper Saddle River, New Jersey, USA.

Wolfe, L. L., M. W. Miller, AND E. S. Williams. 2004. Feasibility of "test-and-cull" for managing chronic wasting disease in urban mule deer. Wildlife Society Bulletin 32:500-505.

WoOlF, A., AND J. L. Roseberry. 1998. Deer management: our profession's symbol of success or failure? Wildlife Society Bulletin 26:515-521.

WYWIALOWSKI, A. 1994. Agricultural producers' perceptions of wildlife-caused losses. Wildlife Society Bulletin 22:370-382.

Kurt C. VerCauteren (left) is the Chronic Wasting Disease Project Leader for the Wildlife Disease Research Program of the National Wildlife Research Center. He received his B.S. from the University of Wisconsin-Stevens Point, and M.S. and Ph.D. from the University of Nebraska-Lincoln. Kurt is a TWS Certified Wildlife Biologist and is on the board of the Society's Wildlife Damage Management Working Group. He has served as Secretary of the Colorado Chapter of The Wildlife Society and as President and Secretary of the Nebraska Chapter. His current research involves devising means to manage Chronic Wasting Disease in wild and captive cervids. John A. Shivik is the leader of the USDA, Wildlife Services (WS), National Wildlife Research Center (NWRC) Logan (Utah) Field Station. He received his B.S. from Frostburg State University (1990), M.S. from the University of California at Berkeley (1995), and Ph.D. from Colorado State University (1999). His current research goals involve incorporating studies of animal behavior and new

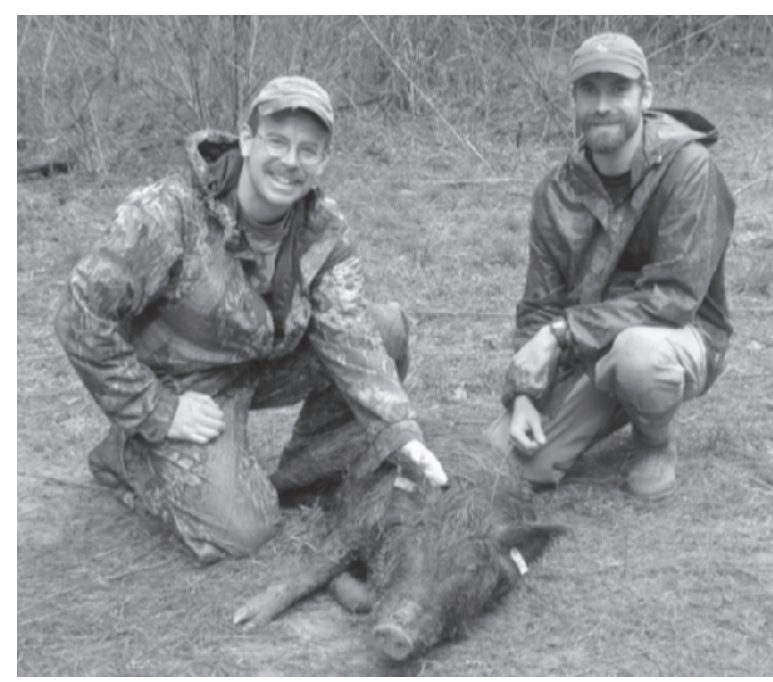

technology into the development of new capture devices and effective non-lethal techniques for managing large predators. Michael J. Lavelle (right) is a biological technician for the Wildlife Disease Research Program of the National Wildlife Research Center. He received his B.S. from the University of Nebraska-Lincoln and is working toward his M.S. from Colorado State University. His research focuses on interactions of cervids and associated risk of disease transmission.

Associate editor: Whittaker

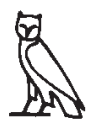

